\title{
Spatial analysis of congenital syphilis in the State of Rio Grande do Norte, between 2008 and 2018
}

\author{
Análise espacial da sífilis congênita no Estado do Rio Grande do Norte, entre 2008 e 2018 \\ Análisis espacial de la sífilis congénita en el Estado de Rio Grande do Norte, entre 2008 y 2018
}

How to cite this article:

Raimundo DML, Sousa GJB, Silva ABP, Almino RHSC, Prado NCC, Silva RAR. Spatial analysis of congenital syphilis in the State of Rio Grande do Norte, between 2008 and 2018. Rev Esc Enferm USP. 2021;55:e20200578. https://doi.org/10.1590/1980-220X-REEUSP-2020-0578

\section{Dhyanine Morais de Lima Raimundo ${ }^{1}$ \\ George Jó Bezerra Sousa² \\ Ana Beatriz Pereira da Silva ${ }^{3}$ \\ Romanniny Hévillyn Silva Costa Almino ${ }^{1}$

(iD) Nanete Carolina da Costa Prado ${ }^{1}$
(iD Richardson Augusto Rosendo da
Silva $^{4}$

${ }^{1}$ Universidade Federal do Rio Grande do Norte, Programa de Pós-Graduação em Enfermagem, Natal, RN, Brazil.

${ }^{2}$ Universidade Estadual do Ceará, Programa de Pós-Graduação em Cuidados Clínicos em Enfermagem e Saúde, Fortaleza, CE, Brazil.

${ }^{3}$ Universidade Federal do Rio Grande do Norte, Natal, RN, Brazil.

${ }^{4}$ Universidade Federal do Rio Grande do Norte, Departamento de Enfermagem, Programa de Pós-Graduação em Enfermagem, Natal, RN, Brazil.

\section{ABSTRACT}

Objective: To analyze the spatial distribution of congenital syphilis cases in a state in northeastern Brazil. Method: This is an ecological study, with secondary data for the period from 2008 to 2018, taking as a sample the notified cases of congenital syphilis in Rio Grande do Norte. In the data analysis, the eight health regions of the state were used as units of analysis, and the local and global Moran's I was performed, with subsequent smoothing through the local empirical Bayesian method, which resulted in thematic maps. Results: The results showed an increase in cases of congenital syphilis in the $3^{\text {rd }}$ and $7^{\text {th }}$ health regions. In terms of spatial analysis, this investigation showed clusters in the $3^{\text {rd }}, 5^{\text {th }}$, and $7^{\text {th }}$ health regions, with an increased risk for congenital syphilis of up to 2.65 times and with an incidence rate of 7.91 cases per 1,000 live births. Conclusion: The spatial analysis of congenital syphilis cases allowed observing a high incidence in some health regions, with averages above those calculated for the entire state, indicating the need to implement effective strategies to achieve its control.

\section{DESCRIPTORS}

Syphilis; Syphilis, Congenital; Spatial Analysis; Geographic Information Systems; Public Health Surveillance. 


\section{INTRODUCTION}

Congenital syphilis (CS) is transmitted from mother to child during pregnancy, having Treponema pallidum as the etiological agent. This disease can have serious consequences for the fetus, such as malformations, stillbirths, fetal and neonatal death ${ }^{(1)}$.

The probability of occurrence of CS depends on the stage of maternal contamination and the duration of fetal exposure $^{(2)}$. Although there are preventive measures for diagnosis, monitoring, and treatment, this disease has been considered the second cause of fetal death worldwide ${ }^{(3)}$. In 2016, the World Health Organization (WHO) launched a program to eliminate $\mathrm{CS}$, which involved the implementation of rapid tests for the diagnosis and proper treatment of pregnant women, setting a goal to year 2030 of reaching an incidence of 50 cases per 1,000 live births or less in $80 \%$ of countries ${ }^{(4)}$.

According to the Epidemiological Bulletin of the Ministry of Health, CS shows an increasing trend in different regions of Brazil, with the Northeast and Southeast regions showing rates above the national rate. While Brazil had an incidence of 8.2 cases per 1,000 live births, the state of Rio Grande do Norte, located in the Northeast region, has an incidence of 13.1 cases/1,000 live births in the past year ${ }^{(5)}$.

In this regard, considering the increase in CS incidence rates and the need to reach the defined goal for its elimination, the development of studies is warranted, using surveillance methods that allow a better situational diagnosis of this disease in the population, supporting the discussion of health strategies and policies to reach its control. Thus, this tool can contribute to the systematic evaluation of the CS epidemiological surveillance system, since it is possible to carry out an analysis of the health situation in a given geographic space. Furthermore, through thematic maps, it is possible to identify whether there are spatial clusters, space-time dependence, as well as to contribute to the monitoring of the epidemiological situation and the establishment of prevention and control measures for this disease ${ }^{(6-8)}$.

Studies carried out in the State of Rio Grande do Sul in the period 2001-2012 ${ }^{(9)}$ and in Espírito Santo between 2011-2018 $8^{(10)}$, which analyzed the spatial distribution of cases of congenital syphilis, identified the increase in this condition in metropolitan regions. In addition, they reinforced the immediate implementation of public policies in favor of actions to control and prevent congenital syphilis in the most affected areas, especially with regard to prenatal care and continuing education of health professionals in Primary Health Care (PHC) $)^{(9-10)}$.

In this respect, the nurse, as a member of the $\mathrm{PHC}$ health team, plays an important role in the fight against congenital syphilis, providing prenatal consultations to the pregnant woman and her partner, counseling, rapid testing, notification of this disease, provision of guidance, clarification of doubts, and follow-up of cases with reactive serology $y^{(11)}$.

Thus, this study aimed at analyzing the spatial distribution of congenital syphilis cases in a state in northeastern Brazil.

\section{METHOD}

\section{Type OF Study}

This is an ecological, longitudinal study with a quantitative approach using as units of analysis the eight health regions $(R S)$ of the State of Rio Grande do Norte, Northeastern Brazil.

\section{Population}

The population studied was that of CS cases, which had 3,550 children notified from January 1, 2008 to December 31,2018. Thus, all new cases of CS notified and confirmed in the Information System of Notifiable Diseases (SINAN) were included in the study in that period. SINAN is formed by a set of variables obtained through the disease notification and monitoring formulary.

\section{LOCAL}

The study was carried out in the State of Rio Grande do Norte (RN), using secondary data related to CS. The state of $\mathrm{RN}$ is divided into eight Health Regions, which will be the study units of analysis. The $R S s$ are called Regional Public Health Units (URSAP), on the basis of the Master Plan for Regionalization - PDR/RN and the Decree 7.058 of June 28, 2011, which, besides other provisions, concerns the health planning and the interfederative articulation ${ }^{(12-13)}$.

The $1^{\text {st }} R S$ covers 27 municipalities(14), has two reference hospitals ${ }^{(15)}$ and covers $100 \%$ of the population in Primary Health Care ${ }^{(13)}$, where $70 \%$ of the procedures are performed at this level of complexity. This region is integrated into the Urgency and Emergency Care Network of the Metropolitan Region ${ }^{(14)}$.

The $2^{\text {nd }} R S$, which comprises 14 municipalities ${ }^{(16)}$, has between 80 and $100 \%$ of the population covered by PHC teams ${ }^{(13)}$. The region offers $45.01 \%$ of services in Primary Care, $41 \%$ of medium complexity, and $13.8 \%$ of high complexity. Besides its own headquarters for the Mobile Emergency Care Service (SAMU-192), this region has a Regional Blood Center and a transfusion agency ${ }^{(14)}$.

The $3^{\text {rd }} R S$, with 26 municipalities, has $100 \%$ of the population covered by PHC teams ${ }^{(16)}$, where more than $65 \%$ of the procedures are performed. For medium-complexity care, it has only 1 hospital, accounting for $34.61 \%$ of consultations, with no high-complexity procedures available according to the State Health Plan ${ }^{(13)}$.

Regarding the $4^{\text {th }} R S$, it integrates 25 municipalities and has $100 \%$ of the population covered by the $\mathrm{PHC}^{(13)}$, where $49.69 \%$ of the procedures are performed. As for specialized care, $29.88 \%$ of the services are offered and $20.12 \%$ of the services are highly complex, distributed in the three hospitals available in the region ${ }^{(14)}$.

Regarding the $5^{\text {th }} R S, 21$ municipalities are part of this region. The population is $100 \%$ covered by $\mathrm{PHC}^{(13)}$, accounting for $49.62 \%$ of the procedures. Medium complexity, on the other hand, accounts for $49.56 \%$ of the consultations and there is no service for high complex cases. The region has two hospitals ${ }^{(14)}$. 
The $6^{\text {th }} R S$ has 37 municipalities with population coverage ranging from 80 to $100 \%$ of the $\mathrm{PHC}$ services ${ }^{(13)}$, where $59.16 \%$ of the services are provided. Medium complexity services comprise $28.47 \%$ of procedures and high-complexity care service accounts for $12 \%$ of services. This region relies on the services of three hospitals and a collection and transfusion unit ${ }^{(14)}$.

Regarding the $7^{\text {th }} R S$, despite covering only five municipalities ${ }^{(14)}$, the PHC in Natal, the state capital, has a population coverage below $62 \%$, while the other municipalities range from 80 to $100 \%{ }^{(13)}$. PHC accounts for $22.20 \%$ of the assistance, while the medium complexity coverage reaches $37.91 \%$, and the high complexity, $40.84 \%$. In this URSAP, several hospitals, clinics, and laboratories are part of the list of services, and they are reference for the entire state of Rio Grande do Norte.

Finally, the $8^{\text {th }} R S$ integrates 12 municipalities and has $100 \%$ of the population covered by the PHC, which performs $43.31 \%$ of the services; medium complexity care, in its turn, covers $47.83 \%$, and high complexity only $8.61 \%$, distributed in four hospitals in the region ${ }^{(13)}$.

\section{Selection Criteria}

Every case notified to the SINAN of a child under 13 years of age with clinical manifestation or a positive diagnostic test at the time of delivery, or whose mother presented positive serological test for syphilis during the prenatal period and/or childbirth/puerperium, or newborn, stillbirth, or miscarriage with untreated or inadequately treated syphilis ${ }^{(17)}$ was defined as CS. All cases included were residents of the municipalities of Rio Grande do Norte.

\section{Data Collection}

In December 2019, the database of CS cases included in SINAN was obtained from the Health Department of the State of Rio Grande do Norte. Once in possession of the database, these data were registered and tabulated in a spreadsheet in the software Microsoft software for the organization of the georeferenced database.

The number of live births, to calculate incidences, was obtained from the Information System on Live Births, available on the website of the Information Technology Department of the Brazilian Public Health System. Regarding cartographic data referring to the state and population size, they were obtained by the Brazilian Institute of Geography and Statistics on its website.

\section{Data Analysis and Treatment}

The mean gross incidence rate of $\mathrm{CS}$ was calculated for each $R S$ in the indicated period using the mean number of new cases in the numerator and the number of live births as the denominator, multiplied by 1,000 inhabitants.

For the spatial analysis, the thematic map of the incidence in each $R S$ was created and then these rates were smoothed using the local empirical Bayesian method to reduce instabilities caused by differences among regions. This method considers not only the value of the studied region, but it weights it in relation to the border regions through a spatial proximity matrix, taking into account the contiguity criterion in which value 1 is assigned to regions that have borders in common and 0 to regions that do not share borders.

After descriptive analysis, the presence of spatial dependence was verified through the Global Moran's I on the raw indicator. The method identifies the spatial autocorrelation and varies between -1 and +1 , where values close to zero indicate absence of spatial dependence, considering $\mathrm{p}<0.05$ as significant. In addition, the local autocorrelation (Local Index of Spatial Association - LISA) was evaluated by the Local Moran's I, which checks the value of the municipality with that of its neighbors with identification of spatial patterns ${ }^{(18)}$.

The Local Moran's I identifies four quadrants: high-high (regions with high rates and surrounded by those with high rates), low-low (regions with low rates surrounded by those with low rates), high-low (regions with high rates surrounded by those with low rates) and low-high (regions with low rates surrounded by those with high rates), with values 1 with $\mathrm{p}<0.05$ being considered significant. The high-high and low-low categories represent areas of agreement and the high-low and low-high categories indicate areas of epidemiological transition ${ }^{(18)}$.

Then, the spatial scan analysis, called scan statistics, was performed. It was used to identify areas of risk and protection for the incidence of the disease. For this, the RR of each municipality for mortality was calculated and the presence of purely spatial clusters was identified ${ }^{(19)}$.

To identify the purely spatial clusters, the discrete Poisson model was used, with the following requirements: no geographic overlap of clusters, maximum cluster size equal to $50.0 \%$ of the exposed population, circular clusters, and 999 replications.

Calculations of gross and smoothed rate, as well as the Moran Scatter Plot and its significance, were made by the software TerraView 4.2.2. The purely spatial scan analysis was performed using the software SaTScan 9.6. All maps were produced in software QGIS 2.4.17.

\section{Ethical Aspects}

The study was approved by the Ethics and Research Committee of the Universidade Federal do Rio Grande do Norte under opinion No. 3.775.828, in 2019, in accordance with national regulation 466/2012 for research involving human beings.

\section{RESULTS}

This study resulted in the mean gross incidences in the eight $R S$ in the state in the proposed period. We infer that the highest incidences occurred in the $7^{\text {th }}, 3^{\text {rd }}$ and $1^{\text {st }} R S s$ with $11.48,9.34$, and 8.48 cases per 1,000 live births, respectively, with averages much higher than those calculated for the entire state of Rio Grande do Norte of 7.91 cases per 1,000 live births. 
When analyzing the correlation coefficients and spatial clustering according to Moran's method, the $1^{\text {st }}, 3^{\text {rd }}$, and $5^{\text {th }} R S s$ show high-high and high-low correlations. The $7^{\text {th }} R S$ presents a high-high correlation throughout its extension. In their turn, the $2^{\text {nd }}, 4^{\text {th }}$, and $6^{\text {th }} R S s$ show a low-low correlation. Furthermore, there is a large extension of the state where this relationship cannot be checked due to the low notification numbers collected in some periods of the study (Figure 1).

Based on this, it is possible to observe, through Figure 2, that the local Moran (LISA) shows how significant these spatial correlations are, based on the clusters of municipalities with $\mathrm{p}<0.01$ in the $1^{\text {st }}, 2^{\text {nd }}, 4^{\text {th }}, 5^{\text {th }}$ and $6^{\text {th }} R S$ s. Except for the $8^{\text {th }}$, the other $R S$ s have municipalities with $\mathrm{p}<0.001$,

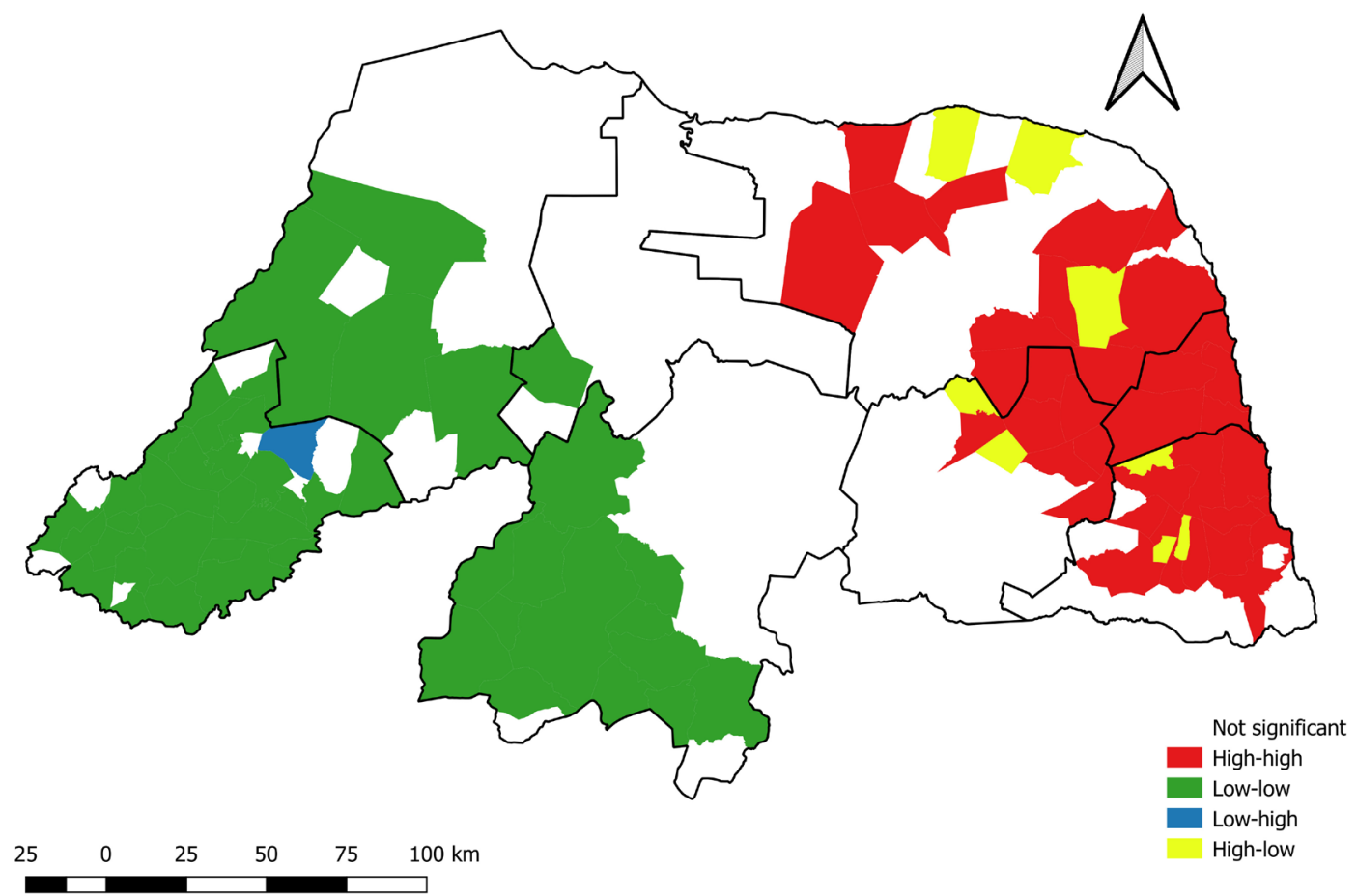

Figure 1 - Spatial correlation of the Global Moran type.
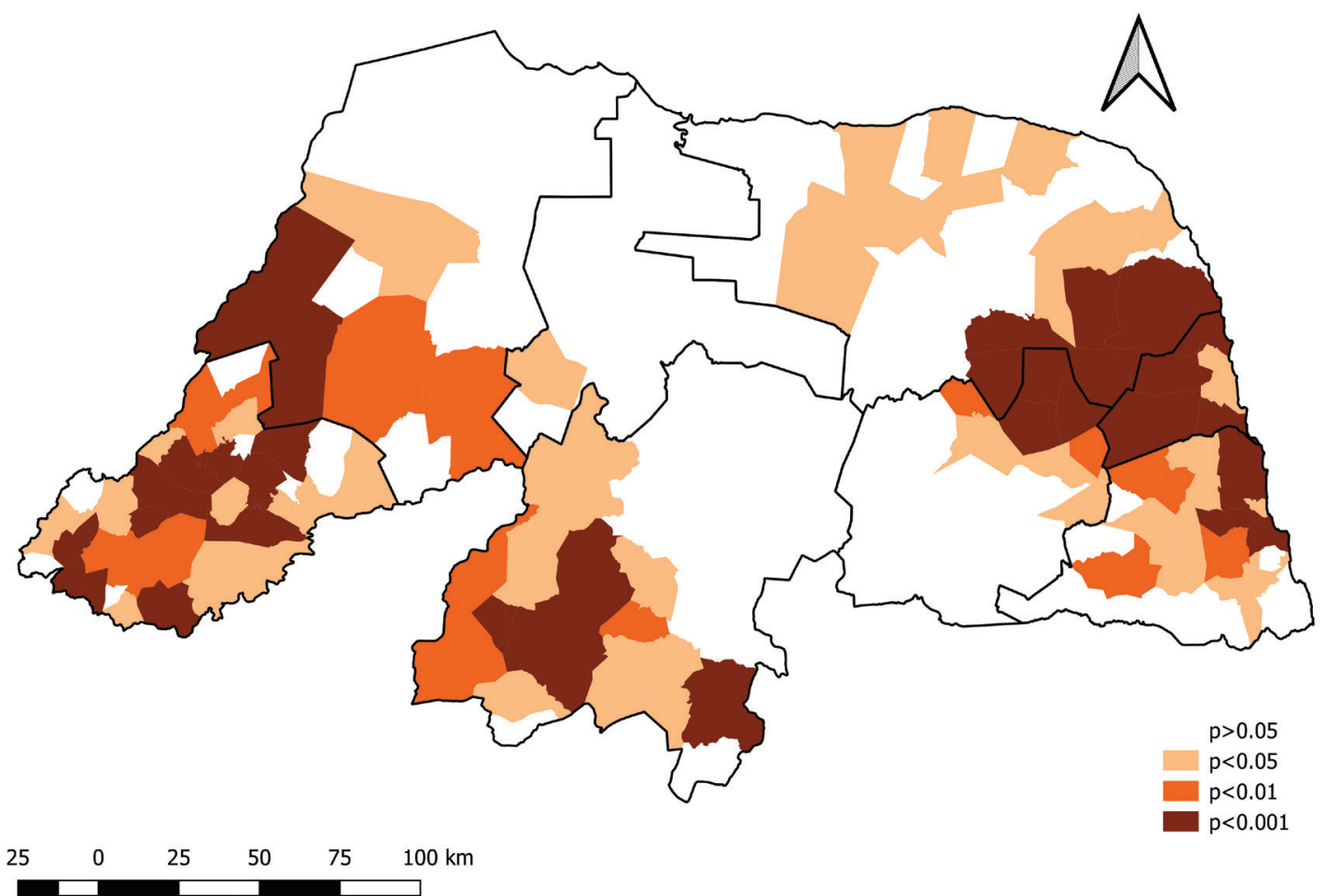

Figure 2 - Local Moran (LISA) with spatial correlations and clusters of municipalities. 


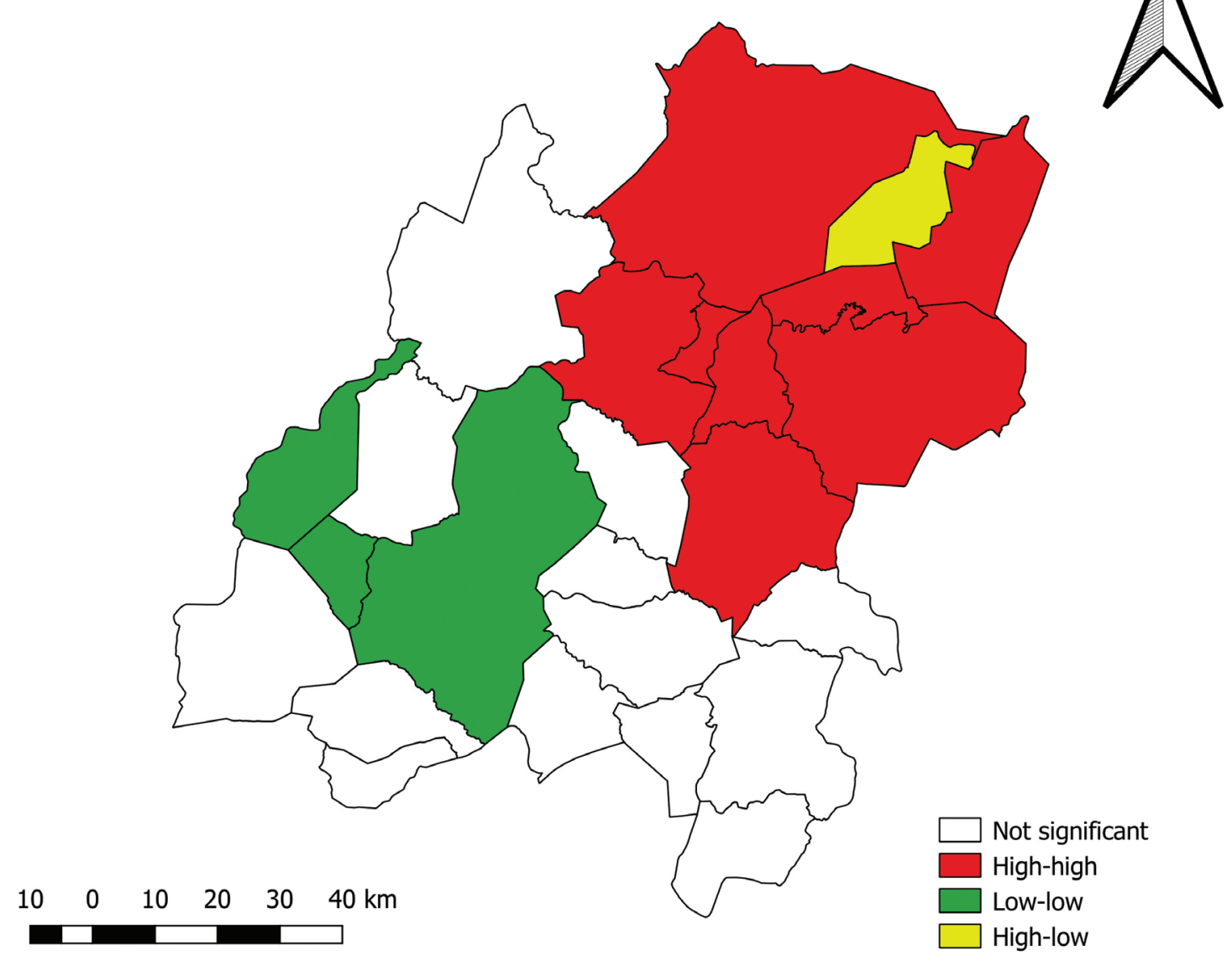

Figure 3 - Significant Moran's I in the 4th health region, Rio Grande do Norte.

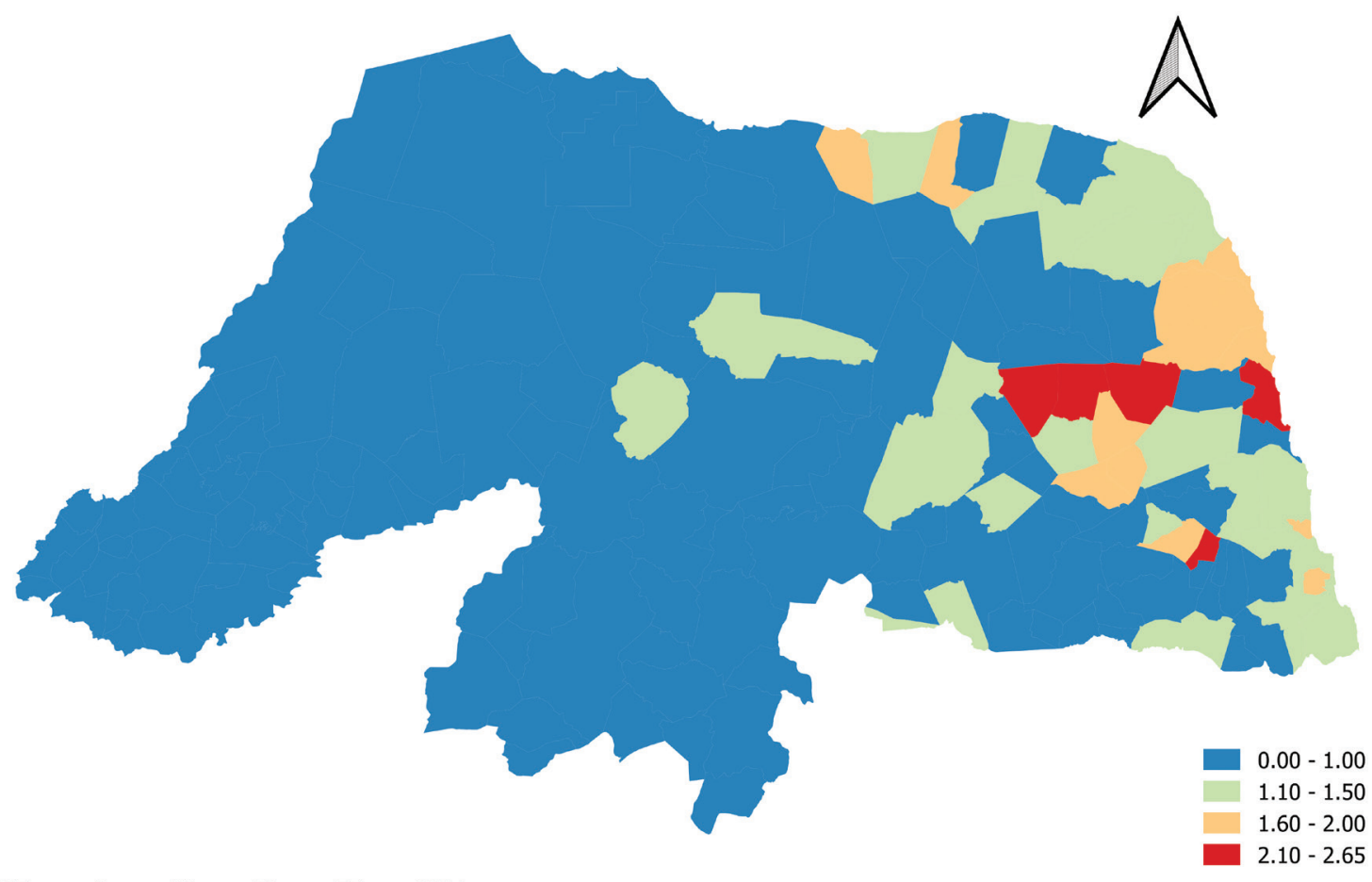

$\begin{array}{llllll}25 & 0 & 25 & 50 & 75 & 100 \mathrm{~km}\end{array}$

Figure 4 - Risk of CS involvement in the municipalities, Rio Grande do Norte. 


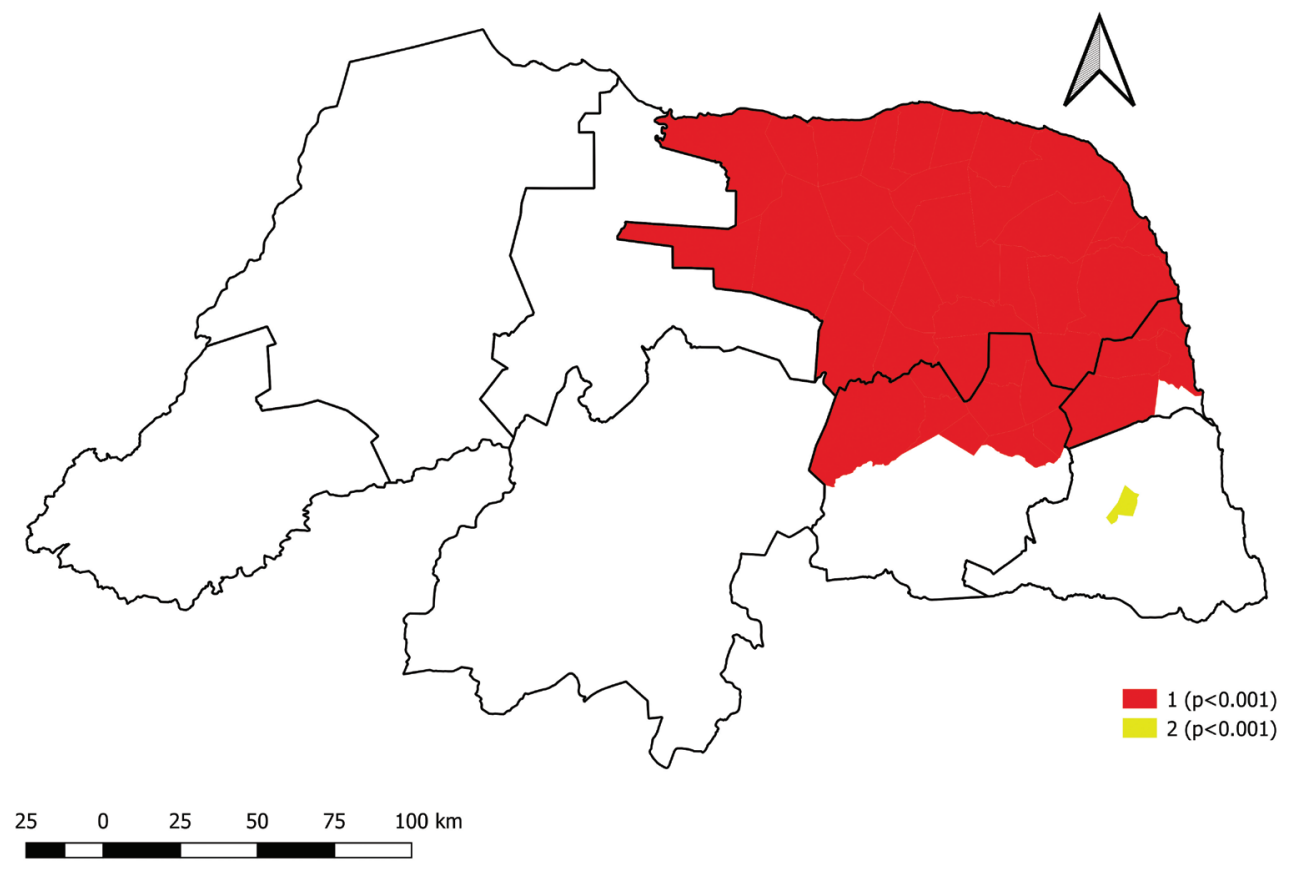

Figure 5 - Spatial cluster of health regions in Rio Grande do Norte.

that is, they have a high degree of spatial correlation, even in $R S$ with low rates of CS cases.

Regarding Moran's I, only the $4^{\text {th }} R S$ presented significance, 0.35 ( $p$-value 0.03 ), with high-high correlations in eight municipalities, high-low in 1 municipality, and low-low in 3 municipalities, which characterizes high spatial correlations (Figure 3).

When performing the spatial scan analysis, which analyzes the risk of syphilis, Figure 4 , the $1^{\text {st }}, 3^{\text {rd }}, 5^{\text {th }}$ and $7^{\text {th }} R S s$ show results in municipalities with a risk ranging from 1.60 to 2.65 more chances of occurrence of CS. It is important to emphasize that the $2^{\text {nd }}, 4^{\text {th }}$ and $6^{\text {th }}$ regions did not have municipalities with increased risk for CS.

With regard to spatial clusters, as shown in Figure 5, it is possible to see that there is a cluster comprising the $3^{\text {rd }}, 5^{\text {th }}$, and $7^{\text {th }} R S s(\mathrm{p}<0.001)$ and a small cluster in the $1^{\text {st }}$ health region $(\mathrm{p}<0.001)$.

\section{DISCUSSION}

The study showed the epidemiological situation of CS in the State of RN in the period from 2008 to 2018, with the $1^{\text {st }}, 3^{\text {rd }}$, and $7^{\text {th }} R S s$ categorized with very high incidences, the $2^{\text {nd }}, 5^{\text {th }}$, and $8^{\text {th }} R S$ with high rates, while the $4^{\text {th }}$ and $6^{\text {th }} R S s$ with intermediate level ${ }^{(20)}$, according to the classification defined by the World Health Organization. This situation may be related to several factors, such as: difficulty in making an early diagnosis of GS and having patients adhere to treatment; improvement in case detection by the epidemiological surveillance system; shortage of Benzatine Penicillin, which is the main drug used to treat infected patients and prevent mother-to-child transmission, and the non-administration of this drug in Primary Care; as well as the low quality of prenatal consultations.
It should be noted that early detection of Gestational Syphilis (GS), counseling, adequate case management, including treatment of the pregnant woman and her partner, and awareness of condom use are the only viable and very accessible methods to promote decline of this disease ${ }^{(21)}$.

The $7^{\text {th }} R S$, also called Metropolitan Region, although being the smallest region in terms of municipalities, had the highest SC notification rates and, consequently, the highest incidence in this study ${ }^{(5)}$, even above the national rate, which was 8.2 cases per 1,000 live births. This may be related to the population contingent of $38.2 \%$ being concentrated in this region, although there has been a tendency for couples to carry out family planning since $2010^{(13)}$. Furthermore, there is a concentration of health services in this region, favoring the expansion of prenatal care and the offer of treatment for syphilis in PHC and maternity hospitals, but what has been sensitive in this study is that there is a lack of control regarding CS.

Unlike this finding, in the United States of America, with regard to the number of cases, mortality and morbidity due to CS, there was an annual reduction, and the year 2012 had the lowest number of reported cases since the changes in criteria of diagnoses established in $1988^{(22)}$.

Nevertheless, this study shows that the $6^{\text {th }} R S$, located in the Upper West region, concentrates the lowest incidences related to CS notification in the period studied, but encompasses a greater number of municipalities with a total of 37. This epidemiological situation may be related to the coverage of the Family Health Strategy above 90\% since 2006, suggesting the implementation of effective prevention measures. On the other hand, regarding Epidemiological Surveillance in this region ${ }^{(13)}$, there is a need to restructure laboratories to perform treponemal and non-treponemal tests to contribute to the diagnosis of gestational syphilis, 
which generates greater control of CS. Thus, it is possible that there are many unreported and untreated cases in this region.

However, even with the advance of the Center of Regulation of Obstetric Emergencies in the State of RN, the $6^{\text {th }} R S$ does not yet have a reference maternity hospital that favors the early detection and notification of CS cases ${ }^{(23)}$. When a referral of pregnant woman is required through this service, she is referred to the surrounding health regions, where the notification is registered. This may explain the low rates of $\mathrm{SC}$ in the period of this study in this region.

The same can be observed in the $2^{\text {nd }}, 4^{\text {th }}$, and $8^{\text {th }} R S s$, where it is possible to infer that there may be weaknesses regarding notification, since these regions, although having a large number of municipalities, resulted in low or even no notifications, such as it is possible to identify in 2008, 2010 and 2011. This situation highlights the quality of monitoring carried out during prenatal care and childbirth to prevent vertical transmission of syphilis, as studies indicate that, in Brazil, medium-sized and small-sized municipalities have a better coverage of the FHS and, consequently, a greater capacity to detect cases of syphilis ${ }^{(24)}$.

Since GS is not diagnosed and treated in a timely manner, it is transmitted to the fetus in the uterus or in the postpartum period. This can lead to many complications for the newborn, such as premature birth or stillbirths. This is possibly due to the higher prevalence of severe comorbidities in the mother ${ }^{(25)}$.

By analyzing the spatial correlation coefficients, it is possible to infer that in addition to the $1^{\text {st }}, 3^{\text {rd }}$, and $7^{\text {th }}$, the $5^{\text {th }}$ region results in high-high correlations, that is, municipalities with high incidence rates have neighboring cities with alarming results and exert strong influence among its neighbors, suggesting high-priority intervention towards the prevention of CS. It is suggested that this homogeneous distribution among these $R S s$ is related to the distribution of diagnostic services that serve the four regions mentioned above, such as the State Network of Public Health Laboratories, which is responsible for diagnosing diseases of public health interest and for Epidemiological Surveillance actions $^{(13)}$. Thus, after positive results of treponemal tests, the newborn undergoes a new collection that is destined for non-treponemal evaluation in this laboratory, which results in better diagnoses.

Although this work has identified spatial clusters in several regions, only the $4^{\text {th }} R S$ resulted in a statistically significant Moran's I. Although it has been evaluated as the region that has $100 \%$ of the population covered by $\mathrm{PHC}$, it showed an expressive growth in CS. This situation can show that there are weaknesses in prenatal care, as the high incidence rate of this disease is an indicator capable of pointing out flaws in the quality of this service, considering that good care requires early detection and adequate treatment of infected pregnant women and their partners, interrupting the vertical transmission chain of syphilis ${ }^{(26)}$. It is suggested that greater investments are required for continuing education of health professionals, aiming at improving the quality of prenatal consultations; expansion of the rapid testing offer; dispensing and administration of benzathine penicillin in the Primary Health Care Units $(U B S)$; health surveillance measures, such as mandatory notification, essential for carrying out epidemiological analyses and for providing subsidies for the planning of actions to control GS.

When analyzing the risk of CS involvement in Rio Grande do Norte, we infer that the $1^{\text {st }}, 3^{\text {rd }}, 5^{\text {th }}$ and $7^{\text {th }} R S s$ are up to 2.65 times more likely to have CS cases. This may be related to the population density that these four regions have and the concentration of health services favoring diagnosis and notification, since there is a tendency for infectious diseases to have a higher incidence in larger municipalities, probably due to a greater speed of dissemination in environments with higher population density ${ }^{(27)}$.

According to a 2016 Pan American Health Organization (PAHO) report, the high number of cases of congenital syphilis in Brazil may be related not only to the shortage of benzathine penicillin, but also to the greater availability of testing for syphilis diagnosis and improvement in detection by the epidemiological surveillance system. Moreover, the difficulty of treating pregnant women and their partners in the context of Primary Care can favor the loss of follow-up and effectiveness in the prevention of congenital syphilis, as some users, when referred for treatment in specialized services, may abandon treatment ${ }^{(28)}$.

Such referral may occur due to the fear of professionals of administering this drug in Primary Health Care services, given the possibility of adverse events. The controversies about the administration of benzathine penicillin in $U B S s$ led to the elaboration of a technical note from the Federal Nursing Council, guiding and supporting the administration of this drug in primary health care ${ }^{(29)}$.

The importance of the nursing team work in Primary Health Care services for the prevention of vertical transmission of syphilis is highlighted. It is also important to clarify to professionals that the main adverse events resulting from the administration of benzathine penicillin are related to neurovegetative and vasovagal disorders, such as anxiety, fear and sweating, as sometimes there is fear of administering this drug in these services due to the possibility of adverse events ${ }^{(29)}$. It should be noted that this is the main drug used to treat infected patients, and to prevent motherto-child transmission.

Furthermore, the nurse, in line with the agenda of strategic actions to reduce syphilis in Brazil, including congenital syphilis, can develop the following actions: nursing consultation in prenatal care and in the reproductive planning, with the participation of partners; actions aimed at health education on syphilis prevention, diagnosis, treatment, and surveillance; early detection with rapid testing; VDRL (Venereal Disease Research Laboratory) request for follow-up; referral for syphilis treatment; administration of benzathine penicillin; active search and notification of syphilis cases in the territory ${ }^{(11,30)}$.

Finally, it is important to highlight that the scenario of this study points to the need to improve CS prevention, 
effectiveness in case notifications, availability of rapid tests, improvement in the epidemiological surveillance system, qualification of health professionals, and improvement in users' access to PHC, in addition to the expansion of teams with the implementation of programs such as the Family Health Strategy.

The limitation found in this study refers to the use of secondary data, as they may be related to incomplete reporting information and the possibility of underreporting, contributing to the underestimation of the real epidemiological situation of congenital syphilis in the analyzed State. However, it should be noted that there has been a change related to the improvement of data quality over the 10 years studied, presenting itself as a potential in the present investigation.

\section{CONCLUSION}

The spatial analysis of notified cases of congenital syphilis in the State of Rio Grande do Norte showed that the $1^{\text {st }}, 3^{\text {rd }}$, and $7^{\text {th }}$ health regions, with a spatial cluster encompassing the $3^{\text {rd }}, 5^{\text {th }}$, and $7^{\text {th }}$ regions, were the most affected by this disease, with increased risk for congenital syphilis up to 2.65 times in the most affected.

Given the findings of this study, better and more effective prenatal care is required in the State of Rio Grande do Norte, through the development of effective active search strategies, health education actions, increased teams, and coverage of Family Health Strategy to provide the equipment, physical structure, and training for the administration of Benzatine Penicillin in Primary Health Care Units, as well as the development of family planning that go beyond the distribution of condoms.

The situational analysis of the territory in which it operates based on spatial analysis can collaborate with the implementation of more effective actions aimed at the active search and notification of cases, health education, nursing consultation in prenatal care, and reproductive planning. This way, more targeted and qualified care aimed at promoting health, preventing and treating syphilis will be provided.

\section{RESUMO}

Objetivo: Analisar a distribuição espacial dos casos de sífilis congênita em um Estado do Nordeste do Brasil. Método: Trata-se de um estudo ecológico, com dados secundários referentes ao período de 2008 a 2018, tendo como amostra os casos notificados de sífilis congênita no Rio Grande do Norte. Na análise dos dados foram utilizados como unidades de análise as oito regiões de saúde do Estado e realizado o índice de Moran local e global, com posterior suavização por meio do método bayesiano empírico local que resultou nos mapas temáticos. Resultados: Os resultados evidenciaram aumento dos casos de sífilis congênita na $3^{\mathrm{a}}$ e $7^{\mathrm{a}}$ regiões de saúde. Em se tratando da análise espacial, esta investigação evidenciou cluster na $3^{\text {a }}, 5^{\text {a }}$ e $7^{\text {a }}$ regiões de saúde, com risco aumentado para sífilis congênita em até 2,65 vezes e com taxa de incidência de 7,91 casos por 1.000 nascidos vivos. Conclusão: A análise espacial dos casos de sífilis congênita permitiu visualizar alta incidência em algumas regiões de saúde, com médias acima da calculada para todo o Estado, apontando a necessidade de implementação de estratégias efetivas para alcançar o seu controle.

\section{DESCRITORES}

Sífilis; Sífilis Congênita; Análise Espacial; Sistemas de Informação Geográfica; Vigilância em Saúde Pública.

\section{RESUMEN}

Objetivo: Analizar la distribución espacial de los casos de sífilis congénita en un Estado en Noreste de Brasil. Método: Se refiere a un estudio ecológico, con datos secundarios referente al periodo entre 2008 a 2018, utilizando como muestra los casos notificados de sífilis congénita en Rio Grande do Norte. En el análisis de los datos fueron utilizados como centros de análisis las ocho regiones de salud del Estado donde se aplicó el índice de Moran local y global, con posterior disminución a través del método bayesiano empírico local que resultó los mapas temáticos. Resultados: Los resultados evidenciaron aumento de los casos de sífilis congénita en la $3^{\mathrm{a}} \mathrm{y} 7^{\mathrm{a}}$ regiones de salud. En el tema análisis espacial, esta investigación evidenció cluster en la $3^{\mathrm{a}}, 5^{\mathrm{a}} \mathrm{y} 7^{\mathrm{a}}$ regiones de salud, con riesgo aumentado para sífilis congénita hasta 2,65 veces y con tasa de incidencia de 7,91 casos por 1000 nacidos vivos. Consideraciones Finales: E1 análisis espacial de los casos de sífilis congénita posibilitó visualizar alta incidencia en algunas regiones de salud, con promedios superiores a los calculados para todo el estado, de esa manera se pudo averiguar la necesidad de implementación de estrategias efectivas para obtener su control.

\section{DESCRIPTORES}

Sífilis; Sífilis Congénita; Análisis Espacial; Sistemas de Información Geográfica; Vigilancia en Salud Pública.

\section{REFERENCES}

1. Brasil. Ministério da Saúde. Guia de Vigilância em Saúde: volume único [Internet]. Brasília; 2017 [cited 2020 July 1]. Available from: http://portalarquivos.saude.gov.br/images/pdf/2017/outubro/06/Volume-Unico-2017.pdf.

2. Brasil. Ministério da Saúde. Protocolo Clínico e Diretrizes Terapêuticas para Prevenção da Transmissão Vertical do HIV, Sífilis e Hepatites Virais [Internet]. Brasília; 2019 [cited 2020 July 1]. Available from: http://www.aids.gov.br/pt-br/pub/2015/protocolo-clinico-e-diretrizesterapeuticas-para-prevencao-da-transmissao-vertical-de-hiv.

3. Figueiredo DCMM, Figueiredo AM, Souza TKB, Tavares G, Vianna RPT. Relação entre oferta de diagnóstico e tratamento da sífilis na atenção básica sobre a incidência de sífilis gestacional e congênita. Cad Saúde Pública [Internet]. 2020 [cited 2020 Nov 1];36(3):e00074519. Available from: https://www.scielo.br/scielo.php?script=sci_arttext\&pid=S0102-311X2020000305009\&tlng=pt.

4. World Health Organization. Global guindance on criteria processes for validation: elimination of mother-to-child transmission of HIV and syphilis [Internet]. Geneva: WHO; 2019 [cited 2020 July 1]. Available from: https://apps.who.int/iris/bitstream/hand le/10665/259517/9789241513272-eng.pdf;jsessionid=BCF6FC0F816A197DE0D7AF90EBF8FF72? sequence=1. 
5. Brasil. Ministério da Saúde. Boletim Epidemiológico Especial - Sífilis 2020 [Internet]. Brasília; 2020 [cited 2020 July 3]. Available from: http://www.aids.gov.br/pt-br/pub/2020/boletim-sifilis-2020.

6. Câmara G, Monteiro AMV, Druck S, Carvalho MS. Análise Espacial e Geoprocessamento [Internet]. Brasília; 2004 [cited 2020 July 1]. Available from: http://www.dpi.inpe.br/gilberto/livro/analise/cap1-intro.pdf.

7. Brasil. Ministério da Saúde. Abordagens espaciais em Saúde Pública [Internet]. Brasília; 2007 [cited 2020 July 3]. Available from: http:// bvsms.saude.gov.br/bvs/publicacoes/serie_geoproc_vol_1.pdf.

8. Carvalho MS, Pina MF, Santos SM, Organizadores. Conceitos básicos de sistemas de informação geográfica e cartografia aplicados à saúde, 2000. OPAS: Brasília; 2000.

9. Teixeira LO, Belarmino V, Gonçalves CV, Mendoza-Sassi RA. Tendência temporal e distribuição espacial da sífilis congênita no estado do Rio Grande do Sul entre 2001 e 2012. Ciênc saúde coletiva [Internet]. 2018 [cited 2021 Mar 21];23(8):2587-97. Available from: https:// www.scielo.br/pdf/csc/v23n8/1413-8123-csc-23-08-2587.pdf.

10. Soares KKS, Prado TND, Zandonade E, Moreira-Silva SF, Miranda AE. Análise espacial da sífilis em gestantes e sífilis congênita no estado do Espírito Santo, 2011-2018. Epidemiol Serv Saúde [Internet]. 2020 [cited 2021 Mar 21];29(1):e2018193. Available from: https://www. scielo.br/pdf/ress/v29n1/2237-9622-ress-29-01-e2018193.pdf.

11. Beck EQ, Souza MHT. Práticas de enfermagem acerca do controle da sífilis congênita. Rev pesqui cuid fundam [Internet]. 2018 [cited 2021 Mar 21];10(3, n. esp):19-24. Available from: http://www.seer.unirio.br/cuidadofundamental/article/view/7596.

12. Brasil. Decreto n. 7.508, de 28 de Junho de 2011 [Internet]. Brasília; 2011 [cited 2020 July 1]. Available from: http://www.planalto.gov. br/ccivil_03/_ato2011-2014/2011/decreto/d7508.htm.

13. Secretaria de Saúde Pública do Estado do Rio Grande do Norte. Plano Estadual de Saúde - PES 2016 - 2019 [Internet]. Natal; 2016 [cited 2020 Nov 1]. Available from: https://www.conass.org.br/pdf/planos-estaduais-de-saude/RN_PES\%202016-2019\%20VERSAO\%20FINAL. pdf.

14. Secretaria de Saúde Pública do Estado do Rio Grande do Norte. Relatório de Prestação de Contas Gestão do SUS [Internet]. Natal; 2016 [cited 2021 Mar 21]. Available from: http://189.28.128.100/dab/docs/portaldab/documentos/geral/apresentacao_do_estado_ab_ no_rn.pdf.

15. Secretaria de Saúde Pública do Estado do Rio Grande do Norte. Hospital Lindolfo Gomes Vidal - Santo Antônio [Internet]. Santo Antônio; 2013 [cited 2021 Mar 21]. Available from: http://adcon.rn.gov.br/Acervo/Sesap/Conteudo.Asp?Tran=Item\&Targ=7927.

16. Fernandes I. Panorama da regionalização e da implantação das Redes de Atenção à Saúde no Estado RN. Natal: Coordenadoria de Promoção da Saúde-CPS. Subcoordenadoria de Ações de Saúde-SUAS [Internet]. Natal; 2019 [cited 2021 Mar 21]. Available from: https:// webcache.googleusercontent.com/search?q=cache:10-VKBoCoBMJ:https://sigaa.ufrn.br/sigaa/verProducao\%3FidProducao\%3D6510607 \%26key\%3D4e56e4aec60b352538c97db3dcdc92ce+\&cd=1\&hl=pt-BR\&ct=clnk\&gl=br.

17. Brasil. Ministério da Saúde. Boletim Epidemiológico - Sífilis 2017 [Internet]. Brasília; 2017 [cited 2020 Nov 1]. Available from: http:/l www.aids.gov.br/system/tdf/pub/2016/65020/boletim_sifilis_11_2017.pdf?file=1\&type=node\&id=65020\&force=1 .

18. Monteiro LD, Martins-Melo FR, Brito AL, Alencar CH, Heukelbach J. Spatial patterns of leprosy in a hyperendemic state in Northern Brazil, 2001-2012. Rev Saúde Pública [Internet]. 2015 [cited 2020 Nov 1];49:84. Available from: https://www.scielo.br/pdf/rsp/v49/0034-8910rsp-S0034-89102015049005866.pdf.

19. Yamamura M, Freitas IM, Neto MS, Neto FC, Popolin MAP, Arroyo LH, et al. Spatial analysis of avoidable hospitalizations due to tuberculosis in Ribeirao Preto, SP, Brazil (2006-2012). Rev Saúde Pública [Internet]. 2016 [cited 2020 Nov 1];50:20. Available from: https://www.scielo.br/pdf/rsp/v50/0034-8910-rsp-S1518-87872016050006049.pdf.

20. Organización Mundial da la Salud. Organización Panamericana de la Salud (OPAS). Marco para La eliminación de la transmisión maternoinfantil Del VIH, la sífilis, la hepatitis y la enfermedad de Chagas [Internet]. Geneva: Organización Mundial da la Salud; 2017 [cited 2020 Nov 1]. Available from: https://www.paho.org/hq/dmdocuments/2017/2017-cha-etmi-plus-marco-vih-hep-chagas.pdf.

21. Guerra HS, Costa CV, Santos IAB, Silva JM, Barcelos TF. Sífilis congênita: repercussões e desafios. ACM arq catarin med [Internet]. 2017 [cited $2020 \mathrm{Nov}$ 18];46(3):194-202. Available from: http://www.acm.org.br/acm/seer/index.php/arquivos/article/view/94.

22. Su JR, Brooks LC, Davis DW, Torrone EA, Weinstock HS, Kamb ML. Congenital syphilis: trends in mortality and morbidity in the United States, 1999 through 2013. Am J Obstet Gynecol [Internet]. 2016 [cited 2020 Nov 06];214(3):381.e1-9. Available from: https://www.ncbi. nlm.nih.gov/pmc/articles/PMC6463496/pdf/nihms-1019103.pdf.

23. Conselho Nacional de Secretários de Saúde. RN passa a contar com Central de Regulação de Acesso às Urgências iniciando na Obstetrícia [Internet]. Brasília; 2019 [cited 2020 Nov 20]. Available from: https://www.conass.org.br/rn-passa-a-contar-com-central-de-regulacao-deacesso-as-urgencias-iniciando-na-obstetricia/.

24. Arcari JM, Barros APD, Rosa RS, Marchi RD, Martins AB. Perfil do gestor e práticas de gestão municipal no Sistema Único de Saúde (SUS) de acordo com porte populacional nos municípios do estado do Rio Grande do Sul. Ciênc saúde coletiva [Internet]. 2020 [cited 2020 Nov 06];25(2):407-20. Available from: https://www.scielo.br/scielo.php?script=sci_arttext\&pid=S1413-81232020000200407.

25. Asafo-Agyei SB, Antwi S, Nguah SB. HIV infection in severely malnourished children in Kumasi, Ghana: a cross-sectional prospective study. BMC Pediatrics [Internet]. 2013 [cited 2020 Nov 8];13(181):1-7. Available from https://bmcpediatr.biomedcentral.com/track/ pdf/10.1186/1471-2431-13-181.pdf.

26. Martinelli KG, Santos-Neto ET, Gama SGN, Oliveira AE. Adequação do processo da assistência pré-natal segundo os critérios do Programa de Humanização do Pré-natal e Nascimento e Rede Cegonha. Rev Bras Ginecol Obstet [Internet]. 2014 [cited 2020 Nov 20];36(2):56-64. Available from: https://www.scielo.br/pdf/rbgo/v36n2/0100-7203-rbgo-36-02-00056.pdf.

27. Rocha LEC, Thorson AE, Lambiotte R. The Non-linear Health Consequences of Living in Larger Cities. Journal of Urban Health: Bulletin of the New York Academy of Medicine [Internet]. 2015 [cited 2020 Nov 20];92(5):1-15. Available from: https://link.springer.com/content/ pdf/10.1007/s11524-015-9976-x.pdf. 
28. Pan American Health Organization. Elimination of mother-to-child transmission of HIV and syphilis in the Americas. Update 2016 [Internet]. Washington DC: PAHO; 2017 [cited 2021 Apr 10]. Available from: http://iris.paho.org/xmlui/bitstream/hand le/123456789/34072/9789275119556-eng.pdf.

29. Conselho Federal de Enfermagem. Nota técnica COFEN/CTLN n. 03/2017 [Internet]. Brasília; 2017 [cited 2021 Apr 22]. Available from: http://www.cofen.gov.br/wp-content/uploads/2017/06/NOTA-T\%C3\%89CNICA-COFEN-CTLN-N\%C2\%B0-03-2017.pdf.

30. Brasil. Ministério da Saúde. Agenda de ações estratégicas para redução da sífilis no Brasil [Internet]. Brasília; 2017 [cited 2021 Mar 21$]$; Available from: http://www.aids.gov.br/pt-br/pub/2017/agenda-de-acoes-estrategicas-para-reducao-da-sifilis-no-brasil. 